No Correlation of Morpho-Agronomic Traits of Phaseolus vulgaris (Fabaceae) Genotypes and Resistance to Acanthoscelides obtectus (Say) and Zabrotes subfasciatus (Boheman) (Coleoptera: Chrysomelidae) E C Guzzo, J D Vendramim, A F Chiorato, A L Lourenção, S A M Carbonell \& O M B Corrêa

Neotropical Entomology

ISSN 1519-566X

Volume 44

Number 6

Neotrop Entomol (2015) 44:619-625 DOI 10.1007/s13744-015-0315-4

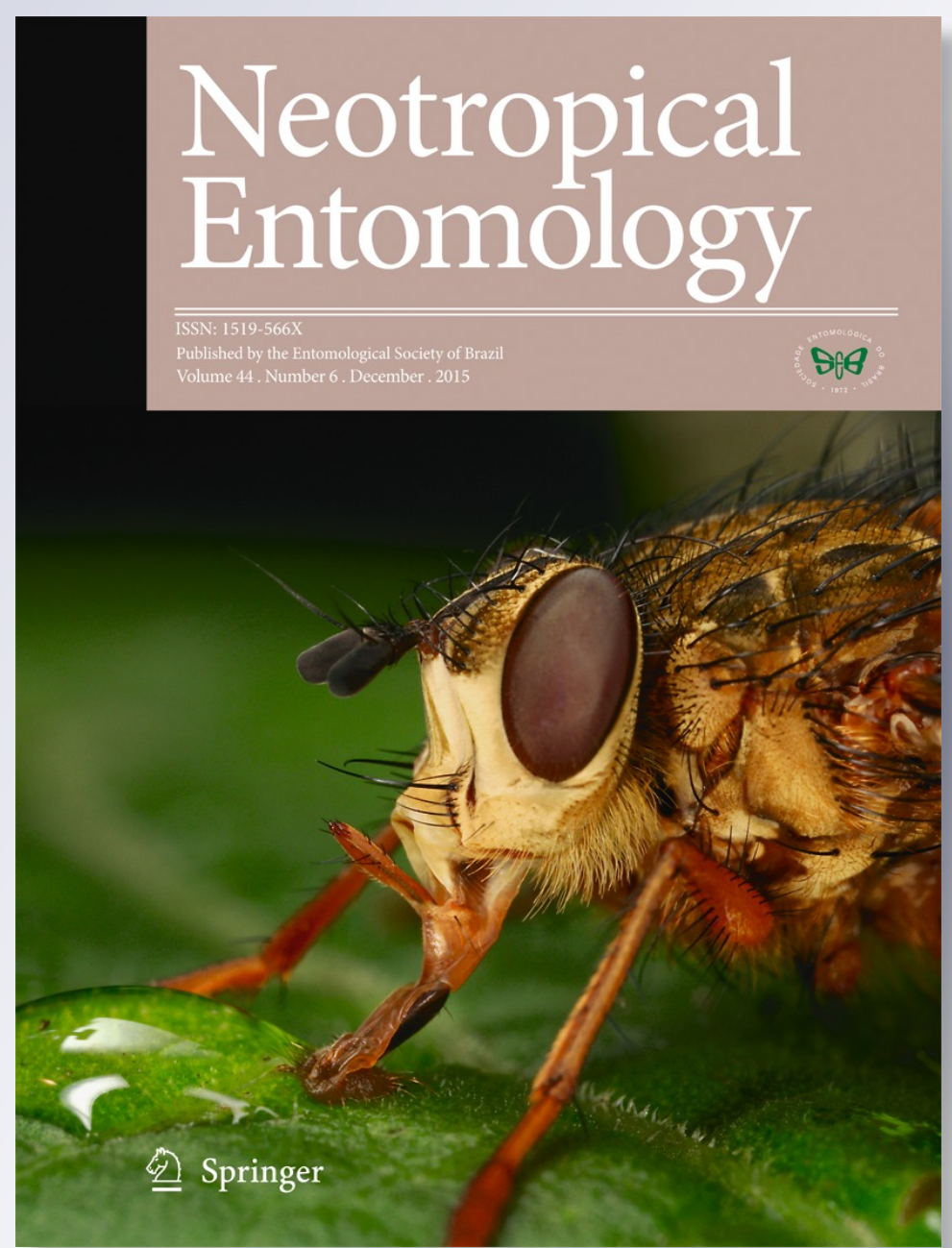

囪 Springer 
Your article is protected by copyright and all rights are held exclusively by Sociedade Entomológica do Brasil. This e-offprint is for personal use only and shall not be selfarchived in electronic repositories. If you wish to self-archive your article, please use the accepted manuscript version for posting on your own website. You may further deposit the accepted manuscript version in any repository, provided it is only made publicly available 12 months after official publication or later and provided acknowledgement is given to the original source of publication and a link is inserted to the published article on Springer's website. The link must be accompanied by the following text: "The final publication is available at link.springer.com". 


\title{
No Correlation of Morpho-Agronomic Traits of Phaseolus vulgaris (Fabaceae) Genotypes and Resistance to Acanthoscelides obtectus (Say) and Zabrotes subfasciatus (Boheman) (Coleoptera: Chrysomelidae)
}

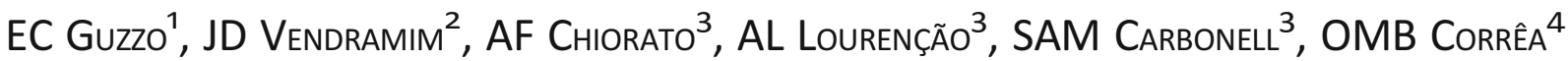 \\ ${ }^{1}$ Embrapa Tabuleiros Costeiros, Maceió, AL, Brasil \\ ${ }^{2}$ Depto de Entomologia e Acarologia, ESALQ, Univ de São Paulo, Piracicaba, SP, Brasil \\ ${ }^{3}$ Instituto Agronômico (IAC), Campinas, SP, Brasil \\ ${ }^{4}$ Univ Metodista de Piracicaba (UNIMEP), Piracicaba, SP, Brasil
}

\section{Keywords}

Arcelin, bean, center of origin, coevolution, host plant resistance, seed beetles

\section{Correspondence \\ EC Guzzo, Embrapa Tabuleiros Costeiros, Cx Postal 2013, 57061-970 Maceió, AL, Brasil; elio.guzzo@embrapa.br \\ Edited by Jorge B Torres - UFRPE \\ Received 1 December 2014 and accepted 10 July 2015 \\ Published online: 8 August 2015 \\ (C) Sociedade Entomológica do Brasil 2015}

\begin{abstract}
Resistance of common bean (Phaseolus vulgaris) varieties is an important tool to control Acanthoscelides obtectus (Say) and Zabrotes subfasciatus (Boheman) (Coleoptera: Chrysomelidae: Bruchinae) worldwide. However, bioassays to characterize the resistance of a genotype can be difficult to perform. Therefore, the current study sought to correlate the morphoagronomic traits of $P$. vulgaris genotypes with their resistance to $A$. obtectus and $Z$. subfasciatus to facilitate genotype characterization. Bean samples of each genotype were infested with newly emerged insect couples, and the number of adults obtained in each genotype was quantified (value used as a resistance parameter). The resistance index was calculated by dividing the number of adults obtained in each genotype by the one obtained in the cultivar Bolinha, used as the standard for susceptibility. Fifty genotypes were evaluated for A. obtectus and 202 for Z. subfasciatus. All genotypes were characterized according to their resistance to each insect and 18 other morpho-agronomic traits, for a total of 19 descriptors. Principal component analyses did not show any correlation between insect resistance and the morpho-agronomic traits of the genotypes. Further, the thousand seeds weight (TSW), which is indicative of the genotype center of origin was tested considering genotypes from Mesoamerican with low TSW, while those from Andean with high TSW. Thus, the lack of correlation between genotype resistance and TSW indicates that resistance to A. obtectus and $Z$. subfasciatus in $P$. vulgaris is not related to the host center of origin.
\end{abstract}

\section{Introduction}

The common bean Phaseolus vulgaris (Fabaceae) originated from the Americas, and its domestication may have occurred independently through two distinct wild varieties $-P$. vulgaris var. mexicanus in the Mesoamerican region and $P$. vulgaris var. aborigineus in South America (Hancock 2004). These varieties differ in a number of features and form hybrids that are mostly sterile (Graham \& Ranalli 1997, Hancock 2004). Over the last 10, ooo years, $P$. vulgaris may have acquired characteristics through its domestication, such as adaptation to neutral photoperiod, changes in plant architecture, the switch from perennial to annual behavior, production of larger and more tender seeds, and the development of more persistent pods (Hancock 2004). 
According to Graham \& Ranalli (1997), insects are the pests that cause the greatest losses in beans in some parts of the world. In Latin America, the predominant pests include the green leafhopper, chrysomelids, and bruchids; while in Africa, stem borers and bruchids are the most significant pests. In Brazil, the seed beetles Acanthoscelides obtectus (Say) and Zabrotes subfasciatus (Boheman) (Coleoptera: Chrysomelidae: Bruchinae) are the main pests of $P$. vulgaris under storage conditions and may coexist in the same warehouse (Vilca Mallqui et al 2013). These two species can be found in all regions of the world where beans are stored (Rossetto 1966), and together, they can cause losses of approximately $25 \%$ in stored beans (Gatehouse et al 1989). Damage caused by $A$. obtectus and $Z$. subfasciatus is similar, and the larvae of both pests bore into the seed cotyledons. Several individuals may be found within a single grain, which may result in the complete destruction of the seed (Athié \& Paula 2002, Hill 2002, Lorini 2002).

The use of resistant varieties is usually considered the ideal solution for insect pest control among the various control methods available, as resistant varieties maintain pest populations below the economic loss threshold without causing disturbance or environmental pollution and without the need for specific knowledge from the farmer. Additionally, the use of resistant varieties is within the principles of Integrated Pest Management (Smith 2005).

The identification of resistant varieties may be based on parameters related to either the plant or the insect (Vendramim \& Guzzo 2009, 2012), and bioassays for characterization of resistacne can be time-consuming and laborintensive. Moreover, such analyses depend on pest colonization in the laboratory as well as the availability of large amounts of the material to be characterized. Thus, the present study sought to correlate the resistance of $P$. vulgaris genotypes to $A$. obtectus and $Z$. subfasciatus with plant morpho-agronomic traits, with the goal to facilitate the characterization of resistant and susceptible genotypes.

\section{Material and Methods}

Insects

The seed beetles $A$. obtectus and Z. subfasciatus used in the bioassays were obtained from the stock colony maintained separately on the susceptible cultivar Bolinha under ambient conditions for several generations.

\section{Bean genotypes}

The $P$. vulgaris genotypes tested were obtained from the Bean Germplasm Bank of the Instituto Agronômico (IAC), Campinas, SP, Brazil. The genotypes studied included wild genotypes, improved materials, cultivars, special seed strains, and others. All of them were multiplied simultaneously to promote uniformity. After harvest, grains were dried in a forced air oven at $28^{\circ} \mathrm{C}$. Final moisture content (13\%) was determined using the oven-drying method at 105 $\pm 3^{\circ} \mathrm{C}$ for $24 \mathrm{~h}$ (Brasil 2009). Then, dried grains were kept in a freezer at $0^{\circ} \mathrm{C}$ until their use to prevent degradation and to eliminate any previous infestation by insect species. Fifty genotypes were evaluated for $A$. obtectus (Table 1) and 202 for Z. subfasciatus (Table 2).

\section{Evaluation of genotype resistance}

For $A$. obtectus, circular transparent plastic pots $(6 \mathrm{~cm}$ diameter and $2 \mathrm{~cm}$ height) were used for each genotype with each one containing 20 bean grains. Two o-24-h-old couples were released per pot for oviposition for 3 days. Afterwards, adults were removed and the number of emerged adults in each pot was determined 50 days later. The mean value of emerged adults for the genotype was used as a resistance parameter. Five replicates were used for each genotype. The same procedure was followed for $Z$. subfasciatus; however, due to the large number of genotypes, they were randomly divided into five sets that were sequentially infested. The susceptible cultivar Bolinha was used in each set to allow the comparison among genotypes.

The resistance level of each genotype was determined according to the relative emergence (RE), which was calculated independently for $A$. obtectus and $Z$. subfasciatus using the following formula: $\operatorname{RE}=(G / C) \times 100$; where $G$ is the number of insects emerged in the respective genotype and $C$ is the number of insects emerged in the control ('Bolinha') of the same set.

\section{Statistical analysis}

The RE and 18 botanical characteristics related to the plant, pods, and seeds of each genotype, as suggested by Singh (1989), Singh et al (1991), and Voysest et al (1994), were used in the analysis, for a total of 19 descriptors. The morphoagronomic descriptors were the thousand seeds weight (TSW), primary seed color, seed brightness, seed shape, number of seed colors, seed halo color, seed profile, seed size, primary pod color, secondary pod color, pod length, pod width, pod profile, number of seeds in the pod, flower wing color, bracteole shape, growth habit, and number of days to flowering. All quantitative variables were categorized, and the results were subjected to principal component analysis using the GENES software (Cruz 2013) independently for A. obtectus and Z. subfasciatus, following Chiorato et al (2006).

Additionally, bean genotypes were grouped into categories according to their resistance to both beetle species. 
Table 1 Average number of Acanthoscelides obtectus adults emerged from Phaseolus vulgaris genotypes at 50 days post-infestation, under confinement testing.

\begin{tabular}{|c|c|c|}
\hline Acessions [Genotype name] & Adults $^{a}$ & Classification $^{b}$ \\
\hline IAC 457 [Cavalo Amarelo] and IAC 612 [Bat-93] & $14.4 \pm 0(14.4)$ & HS \\
\hline $\begin{array}{l}\text { IAC } 834 \text { [FT Bonito], IAC } 618 \text { [Mex-54], IAC } 21 \text { [Baio da Praia], IAC } 623 \text { [G5686], IAC } 937 \text { [Contender], IAC } 628 \\
\text { [Cal-143], IAC } 528 \text { [Type Baetão], IAC } 678 \text { [MAR 3], IAC } 911 \text { [Goytacazes], IAC } 622 \text { [G2858], IAC } 114 \text { [Bataav], } \\
\text { IAC } 121 \text { [Type Rosinha], IAC } 71 \text { [Vermelhinho], IAC } 568 \text { [IAPAR-57], IAC 297 [I-114], IAC } 624 \text { [MAR 1], IAC } 152 \\
\text { [STO ROSS], IAC } 855 \text { [Bolinha CB], IAC } 1 \text { [Frijol Negro], IAC } 596 \text { [IAPAR-BAC } 6 \text { R. Bac.], IAC } 610 \text { [Oito e Nove], } \\
\text { IAC } 707 \text { [IAC-Una], IAC } 374 \text { [Monte Negro-1349], IAC } 478 \text { [México-12], IAC } 655 \text { [A-55], IAC } 630 \text { [HF 465-63-1], } \\
\text { IAC } 28 \text { [Uberabinha], IAC } 597 \text { [IAPAR-31], IAC } 606 \text { [Apetito Branco], IAC } 544 \text { [IAPAR-80], IAC } 633 \text { [RG 1342 } \\
\text { CH60 (MA)], IAC } 921 \text { [Batista Brilhante (CB)], IAC } 445 \text { [B. Porrillo-70], IAC } 586 \text { [ARC-4], IAC 171 [Vermelho } \\
\text { de Minas], IAC } 112 \text { [Type Baetão], IAC 674 [DOR-390], IAC } 533 \text { [Puebla-152], IAC } 89 \text { [Venezuela-350], } \\
\text { IAC } 179 \text { [Manteiguinha], and IAC } 251 \text { [Costa Rica] }\end{array}$ & $7.0 \pm 3.37(13.6-1.6)$ & $S$ \\
\hline $\begin{array}{l}\text { IAC } 215 \text { [Pirata-1], IAC } 556 \text { [Rico-23], IAC } 816 \text { [RAZ-49], IAC } 749 \text { [Car Marrom], IAC } 525 \text { [Type Baetão], } \\
\text { IAC } 584 \text { [ARC-2], and IAC } 615 \text { [A-439 (R.Nem.)] }\end{array}$ & $0.3 \pm 0.28(0.6-0)$ & $\mathrm{R}$ \\
\hline
\end{tabular}

\footnotetext{
${ }^{a}$ Overall mean \pm standard deviation considering all genotypes within a group. Values in parenthesis indicate the extreme values (amplitude) for the genotypes in the group.

${ }^{\mathrm{b}}$ Genotypes were classified according to their resistance level based on the $95 \%$ confidence interval $(95 \% \mathrm{Cl})$ for the $A$. obtectus adults emerged from the susceptible standard cultivar Bolinha. HS (highly susceptible)=values above the $95 \% \mathrm{Cl}$; $\mathrm{S}$ (susceptible)=values within the $95 \% \mathrm{Cl}$; R (resistant)= values below the lower limit of the $95 \% \mathrm{Cl}$.
}

Genotypes were allocated to one of three resistance levels based on the $95 \%$ confidence intervals $(95 \% \mathrm{Cl}$ ) considering the mean number of emerged insects per genotype relative to the cultivar Bolinha, considered the standard for susceptibility, following the classification adopted by Silva et al (2014): resistant (R) for values below the lower limit of the $95 \% \mathrm{Cl}$, susceptible (S) for values within the $95 \% \mathrm{Cl}$, and highly susceptible (HS) for values greater than the upper limit of the $95 \% \mathrm{Cl}$. For genotypes tested against $A$. obtectus, all of them were analyzed together. For genotypes tested against Z. subfasciatus, the procedure was done for genotypes within each set.

\section{Results}

The average number of $A$. obtectus adults obtained in the studied genotypes varied between 0 and 14.4 adults, resulting in $\mathrm{RE}$ values ranging from $\mathrm{O}$ to 189.5, respectively (data not shown). Principal component analysis revealed no correlation between genotype resistance to $A$. obtectus and any of the morpho-agronomic traits analyzed. The first axis explained $23.2 \%$ of the variation whilst the second axis explained $11.5 \%$.

Based on the $95 \%$ confidence interval of the standard susceptible cultivar Bolinha, the tested bean genotypes were clustered into three groups: 2 genotypes were classified as highly susceptible, 41 as susceptible (including the standard susceptible cultivar Bolinha), and 7 as resistant (Table 1).

The average number of emerged adults of $Z$. subfasciatus from the tested genotypes ranged from o to 18.8. Considering that the genotypes of each group were compared to their respective control, the final $R E$ values varied between $O$ and
152.4 (data not shown). Similarly to what was found for A. obtectus, principal component analysis revealed no correlation between genotype resistance to $Z$. subfasciatus and the morpho-agronomic traits analyzed. The first axis accounted for $19.9 \%$ of the variation whilst the second axis for $11.3 \%$.

Based on the $95 \%$ confidence interval of the standard susceptible cultivar (Bolinha), resistance of bean genotypes to $Z$. subfasciatus resulted in the formation of 3 clusters with 1 genotype classified as highly susceptible, 110 genotypes classified as susceptible (including the standard susceptible cultivar Bolinha), and 91 as resistant (Table 2).

\section{Discussion}

The RE based on the number of insects emerged 50 days after infestation alone is not a solid indicator for selection of resistant genotypes, although $R E$ values directly reflect the sum of the possible types and causes of genotype resistance. A low number of emerged adults may be due to genotype antibiosis or to antixenosis for feeding and/or oviposition. These factors could result in high immature mortality, prolonged development, and/or reduced egg laying, all leading, singly or jointly, to a reduced number of adults. Moreover, Rêgo et al (1986) found that the assessment of emerged populations was one of the most consistent parameters for determining the resistance and/or susceptibility of $P$. vulgaris genotypes to $Z$. subfasciatus.

It was also observed that not all resistant genotypes to Z. subfasciatus were resistant to $A$. obtectus and vice versa. For example, the genotype IAC 215, which was found to be resistant to $A$. obtectus, was classified as susceptible to 
Table 2 Average number of Zabrotes subfasciatus adults emerged from Phaseolus vulgaris genotypes at 50 days post-infestation, under confinement testing.

\begin{tabular}{llll}
\hline Set & Acessions [Genotype name] & Adults $^{\text {a }}$ & Classification $^{\text {b }}$ \\
\hline 1 & IAC 674 [DOR-390] & $14.2(14.2)$ & HS \\
& IAC 478 [México-12], IAC 855 [Bolinha CB], IAC 374 [Monte Negro-1349], IAC 112 [Type Baetão], & $10.9 \pm 0.92(12.4-9.8)$ & S
\end{tabular}
IAC 834 [FT-Bonito], IAC 297 [I-114], IAC 1 [Frijol Negro], IAC 607 [Barbunya], and IAC 445 [B. Porrillo-70]

IAC 635 [RIZ-30], IAC 597 [IAPAR-31], IAC 749 [Car Marrom], IAC 611 [Alemão], IAC 556 [Rico-23], IAC 678 [Mar 3], IAC 628 [Cal-143], IAC 596 [IAPAR-BAC 6 R. Bac.], IAC 615 [A-439 (R.Nem.)], IAC 618 [Mex-54], IAC 121 [Type Rosinha], IAC 21 [Baio da Praia], IAC 683 [Xan-251], IAC 49 [IAC Carioca], IAC 624 [MAR 1], IAC 521 [Chileno/Preto], IAC 114 [Bataav], IAC 457 [Cavalo Amarelo], IAC 630 [HF 465-63-1], IAC 179 [Manteiguinha], IAC 612 [Bat-93], IAC 533 [Puebla-152], IAC 623 [G5686], IAC 75 [Bagajo], IAC 672 [IAPAR 81], IAC 588 [Ovo de Codorna Tyunaga Vermelho], IAC 568 [IAPAR57], IAC 595 [CNF-86-9], IAC 528 [Type Baetão], IAC 83 [Type Baetão], IAC 544 [IAPAR-80], IAC 614 [Pinto-114], IAC 577 [Jalo], IAC 71 [Vermelhinho], IAC 682 [Xan-159], IAC 171 [Vermelho de Minas], IAC 622 [G2858], IAC 427 [Safira], IAC 606 [Apetito Branco], IAC 921 [Batista Brilhante (CB)], IAC 911 [Goytacazes], IAC 525 [Type Baetão], IAC 587 [Vermelho Desconhecido], IAC 1081 [CF-840743], Ento A, IAC 621 [A-449], IAC 634 [AND-277 (MA)], IAC 570 [MD-806], IAC 251 [Costa Rica], IAC 610 [Oito e Nove], IAC 584 [ARC-2], IAC 2 [Sanilac], IAC 583 [ARC-1], and IAC 818 [RAZ-59]

2 IAC 89 [Venezuela-350], IAC 633 [RG 1342 CH-60 (MA)], IAC 28 [Uberabinha], IAC 582 [IAPAR-44], IAC 172 [IPA-2], IAC 576 [EMP-81], IAC 465 [Porrillo Sintético], IAC 208 [44/71-85], IAC 385 [IAC Carioca Tybatã], IAC 937 [Contender], IAC 152 [STO ROSS], IAC 707 [IAC-Una], IAC 655 [A-55], IAC 835 [Bolinha CB], IAC 211 [Retinto Santa Rosa], IAC 415 [73 VUL-3205], IAC 1081 [CF-840743], IAC 125 [Chumbinho-63], IAC 575 [RAI-76], IAC 215 [Pirata-1], IAC 677 [DOR-482], Ento B, IAC 559 [Iraí], IAC 602 [R.Bac.], IAC 203 [Rosado-14 (mulatinho)], IAC 186 [Coco Blanchi], IAC 627 [Amendoim], IAC 17 [Rosinha], IAC 1116 [PI 417660], IAC 625 [mar/02], IAC 159 [Aete-2], IAC 225 [México-309], IAC 249 [Preto Uberabinha], and IAC 681 [Xan-112]

IAC 445 [B. Porrillo-70], IAC 586 [ARC-4], IAC 35 [ECU-208], IAC 816 [RAZ-49], and IAC 610 [Oito e Nove]

3 IAC 550 [Caeté (preta)], IAC 73 [Rosinha], IAC 316 [Mamoninha], IAC 546 [Gordo Branco], IAC 385 [México-488], IAC 239 [México-435], IAC 638 [TO], IAC 90 [B. Turrialba], IAC 835 [Bolinha CB], IAC 578 [Tarumã], IAC 566 [Pijão], IAC 56 [ECU-311], IAC 1103 [PR-733639], IAC 679 [Turrialba-1], IAC 1062 [PR-733612], IAC 558 [Mulata Gorda], IAC 637 [TU], IAC 373 [México-498], IAC 107 [Guatemala], IAC 236 [Preto-208], IAC 112 [Type Baetão], IAC 832 [Pérola], IAC 567 [IAPAR-65], IAC 685 [G-5207], and IAC 254 [Quarenteno]

IAC 481 [Carioca MG], IAC 492 [G11796], IAC 585 [ARC-3], and IAC 819 [RAZ-55]

4 IAC 49 [Carioca-80], IAC 569 [IAPAR-72], IAC 354 [Preto-146], IAC 646 [Mex-279], IAC 616 [A-443 (R.Nem.)], IAC 696 [RAPÉ], IAC 186 [Coco Blanchi], IAC 32 [Rosinha-127], IAC 600 [G4000], IAC 673 [MAM-38], IAC 835 [Bolinha CB], IAC 462 [Branco Graúdo], IAC 605 [LP-88-175], IAC 672 [IAPAR-81], IAC 73 [Type Rosinha], IAC 654 [A-21], IAC 589 [Sangre-Toro], IAC 592 [Cal-153], IAC 389 [Small White 59 Preto], IAC 603 [R.Bac.], IAC 863 [Pirapora (CB)], and IAC 649 [A-211]

5 IAC 72 [Alemão], IAC 325 [Rosinha G2], IAC 676 [DOR-476], IAC 599 [AFR-188], IAC 835 [Bolinha CB], IAC 350 [Preto-167], IAC 15 [Type Rosinha], IAC 598 [EMP-408], IAC 1052 [A-285], IAC 571 [A-300], IAC 24 [Rosinha-145-1-1], IAC 71 [Vermelhinho], IAC 398 [Cornell-49242], IAC 643 [PI-207262], IAC 25 [Leg. Floresta-5], IAC 249 [Preto Uberabinha], IAC 619 [Flor de Mayo], IAC 708 [IAC-Maravilha], IAC 590 [Real Mexican-34], IAC 368 [Porrillo-1], IAC 827 [Carioca Comum], IAC 636 [G916], IAC 160 [Uberabinha], and IAC 608 [Pompador]

IAC 653 [Michelite], IAC 196 [HIBC], IAC 222 [Venezuela-42-5-1], IAC 650 [Mex-222], IAC 348 [Preto do Pocrone], IAC 680 [Durango-222], IAC 497 [Terra Velha], IAC 626 [FEB-29], IAC 684 [AND-279], IAC 74 [Enxofre (Diacol Mina Pent)], IAC 675 [DOR-391], IAC 349 [Pato de Minas], IAC 593 [EMP-407], IAC 620 [Pan-72], IAC 296 [Mulatinho], IAC 121 [Type Rosinha], IAC 617 [Bat-332], IAC 681 [Xan-112], IAC 604 [IAPAR-14], IAC 443 [Canário-101], IAC 572 [Jamapa], IAC 837 [IAC Carioca Eté], IAC 149 [Type Baetão], IAC 99 [México-115], IAC 416 [Rosado-13], IAC 138 [Leg. Rosinha], IAC 439 [B-Puebla-40], and IAC 559 [Iraí]

$5.8 \pm 2.7(9.6-0) \quad R$

$7.4 \pm 2.55(12.8-3.4) \quad S$

$0.8 \pm 0.92(2.2-0) \quad R$

$10.7 \pm 1.8(14.6-7.8) \quad S$

$4.2 \pm 2.83(6-0) \quad R$

$10.7 \pm 2.16(13.6-5.8) \quad S$

$16.5 \pm 1.28(18.8 \pm 14.8) \quad S$

$11.7 \pm 2.26(14.6-7.4)$

\section{S}

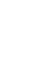


Z. subfasciatus, and the genotype IAC 457 , which was considered resistant to $Z$. subfasciatus, was classified as highly susceptible to $A$. obtectus. These results corroborate data already available for the tested insect species (GuzmánMaldonado et al 1996, Hartweck et al 1997) and the widely available literature showing that plant resistance to insects is species specific (Lara 1991, Panda \& Khush 1995, Smith 2005). Differences in bean resistance to $A$. obtectus and $Z$. subfasciatus were related to the carbohydrate and protein fractions of $P$. vulgaris (Gatehouse et al 1987). While the carbohydrate fraction of a bean strain severely affected the development of $A$. obtectus, but not of $Z$. subfasciatus, the protein fraction of the same strain affected the development of $Z$. subfasciatus but had little or no effect on $A$. obtectus (Gatehouse et al 1987). These results indicate that the basis for resistance to these two pests in the strain tested was different and associated to multiple resistance mechanisms (Minney et al 1990). Thus, it is also possible to infer that genotypes such as IAC 525, IAC 556, IAC 584, IAC 615, IAC 749, and IAC 816, which were resistant to both $A$. obtectus and $Z$. subfasciatus in the present work, possess more than one resistance mechanism.

Arcelin, a toxic protein to several insects including Z. subfasciatus (Cardona et al 1990, Pereira et al 1995, Wanderley et al 1997, Barbosa et al 1999, 2000a, b, 2002, Mazzonetto \& Vendramim 2002, Baldin \& Pereira 2010), but with little or no effect on $A$. obtectus (Guzmán-Maldonado et al 1996, Hartweck et al 1997), is also available in the genotypes IAC 583, IAC 584, IAC 816, IAC 818, and IAC 819, all of them classified as resistant to $Z$. subfasciatus. This may explain the differences in resistance observed for the two species studied here. Arcelin production in $P$. vulgaris is mediated by eight known variants, termed Arc- 1 to Arc- 8 (AcostaGallegos et al 1998, Lioi et al 2003, Zaugg et al 2013), and these variants belong to the lectin family, which also includes phytohemagglutinins and $\alpha$-amylase inhibitors.

The lack of correlation we reported among bean morphological traits and bean susceptibility to $A$. obtectus and Z. subfasciatus has also been reported by GuzmánMaldonado et al (1996). However, these authors were able to demonstrate a negative correlation between the lectin content (a chemical characteristic) in the seed and the oviposition and adult emergence of $Z$. subfasciatus. Although an association between the host bean origin and resistance to a pest has been demonstrated for the pathogen Colletotrichum lindemuthianum (Chiorato et al 2006), we were not able to establish such correlation in our study. Pathogen-host associations are more specific than herbivore-host associations, and this is most likely the reason why there has not been an apparent co-evolution between $P$. vulgaris and $A$. obtectus or between $P$. vulgaris and $Z$. subfasciatus, in contrast to that observed between $P$. vulgaris and C. lindemuthianum.
Thus, it appears that the botanical traits analyzed in the current study in regards to the flower, pod, seed, and plant phenology were not good indicators of genotype resistance to $A$. obtectus and $Z$. subfasciatus. In fact, it was not expected that characteristics such as flower wing color or bracteole shape, for instance, would be directly related to resistance to the tested Bruchinae species. However, it could be possible to a single gene to have multiple phenotypic effects, encoding both a given morpho-agronomic characteristic and a seed beetle resistance trait, or that resistance genes may be linked to other genes conferring those characteristics.

Among the morphological characters used in the present work, the TSW was the one to indirectly provide information about the origin of genotypes. Genotypes with TSW values greater than $41 \mathrm{~g}$ are usually of Andean origin, while those with TSW values lower than $41 \mathrm{~g}$ are of Mesoamerican origin (Gepts 1984, Gepts \& Bliss 1986). According to Hancock (2004), these are the two main centers of origin of beans. As found for both species, $A$. obtectus and $Z$. subfasciatus, the scatter plots of resistance to the insects did not form clusters similar to the genotype TSWs, showing the lack of correlation between these characteristics and indicating that resistance to $A$. obtectus and $Z$. subfasciatus is not related to the genotype center of origin.

Both $A$. obtectus and $Z$. subfasciatus are originally from Central and South Americas (Bondar 1936, Athié \& Paula 2002, Hill 2002) and may have coevolved with common bean. There are wild genotypes and improved materials among the genotypes we tested, whose hybridization levels were not determined. The patterns of the protein phaseolin in cultivated beans are similar to those from wild common beans and landraces from Middle America and the Andean region of South America, supporting the theory that these two regions are the primary areas of bean domestication (Gepts et al 1986). However, phaseolin does not have detrimental effects on seed beetles. Nevertheless, Guzmán-Maldonado et al (1996) did not find correlation between seed protein content and resistance to $A$. obtectus and $Z$. subfasciatus. When principal component analysis was used to explain the genetic variability among bean accessions, the three components that explained $83 \%$ of the variation did not include any physical or chemical seed trait (CIAT 1979 apud Graham \& Ranalli 1997).

Based on our results, we can conclude that there is no correlation between the morpho-agronomic traits of the 50 and 202 bean genotypes tested and their resistance to the seed beetles $A$. obtectus and $Z$. subfasciatus, respectively. This indicates that bioassays, even being time-consuming and labor-intensive, are essential to characterize resistant varieties. The causes for bean genotype resistance to A. obtectus and $Z$. subfasciatus are likely independent and not related to the genotype center of origin. 
Acknowledgments We are grateful to Dr João Gomes da Costa, from Embrapa Tabuleiros Costeiros, for helping us with statistical analysis. We also thank the Brazilian agencies Conselho Nacional de Desenvolvimento Científico e Tecnológico (CNPq) and Coordenação de Aperfeiçoamento de Pessoal de Nível Superior (CAPES) for fellowships.

\section{References}

Acosta-Gallegos JA, Quintero C, Vargas J, Toro O, Tohme J, Cardona C (1998) A new variant of arcelin in wild common bean, Phaseolus vulgaris L. from southern Mexico. Genet Resour Crop Evol 45:235242

Athié I, Paula DC (2002) Insetos de grãos armazenados: Aspectos biológicos e identificação. São Paulo, Livraria Varela, $244 \mathrm{p}$

Baldin ELL, Pereira JM (2010) Resistência de genótipos de feijoeiro a Zabrotes subfasciatus (Bohemann, 1833) (Coleoptera: Bruchidae). Ciênc Agrotecnol 34:1507-1513. doi:10.1590/S141370542010000600022

Barbosa FR, Yokoyama M, Pereira PAA, Zimmermann FJP (2002) Controle do caruncho-do-feijoeiro Zabrotes subfasciatus com óleos vegetais, munha, materiais inertes e malathion. Pesq Agrop Brasileira 37:1213-1217

Barbosa FR, Yokoyama M, Pereira PAA, Zimmermann FJP (1999) Efeito da proteína arcelina na biologia de Zabrotes subfasciatus (Boheman 1833), em feijoeiro. Pesq Agrop Brasileira 34:1805-1810

Barbosa FR, Yokoyama M, Pereira PAA, Zimmermann FJP (2000a) Danos de Zabrotes subfasciatus (Boh.) (Coleoptera: Bruchidae) em linhagens de feijoeiro (Phaseolus vulgaris L.) contendo arcelina. An Soc Entomol Bras 29:113-121

Barbosa FR, Yokoyama M, Pereira PAA, Zimmermann FJP (200ob) Estabilidade da resistência a Zabrotes subfasciatus conferida pela proteína arcelina, em feijoeiro. Pesq Agrop Brasileira 35:895-900

Bondar G (1936) Notas biológicas sobre bruchideos observados no Brasil. Arq Inst Biol Veg 3:7-44

Brasil (2009) Regras para análise de sementes. Brasília, Ministério da Agricultura, Pecuária e Abastecimento: MAPA/ACS, 399p. http:// www.agricultura.gov.br/arq_editor/file/2946_regras_analise_ sementes.pdf. Accessed 24 Apr 2015

Cardona C, Kornegay J, Posso CE, Morales F, Ramirez H (1990) Comparative value of four arcelin variants in the development of dry bean lines resistant to the Mexican bean weevil. Entomol Exp Appl 56:197-206

Chiorato AF, Carbonell SAM, de Moura RR, Ito MF, Colombo CA (2006) Co-evolução entre raças fisiológicas de Colletotrichum lindemuthianum e feijoeiro. Bragantia 65:381-388

Cruz CD (2013) GENES-a software package for analysis in experimental statistics and quantitative genetics. Acta Sci 35:271-276

Gatehouse AMR, Shackley SJ, Fenton KA, Bryden J (1989) Mechanism of seed lectin tolerance by a major insect storage pest of Phaseolus vulgaris, Acanthoscelides obtectus. J Sci Food Agric 47:269-280

Gatehouse AMR, Dobie P, Hodges RJ, Meik J, Pusztai A, Boulter D (1987) Role of carbohydrates in insect resistance in Phaseolus vulgaris. J Insect Physiol 33:843-850

Gepts P (1984) Enhanced available methionine concentration associated with higher phaseolin levels in common bean seeds. Theor Appl Genet 69:47-53

Gepts P, Bliss FA (1986) Phaseolin variability among wild and cultivated common beans (Phaseolus vulgaris) from Colombia. Econ Bot 40 : 469-478

Gepts P, Osborn TC, Rashka K, Bliss FA (1986) Phaseolin-protein variability in wild forms and landraces of the common bean (Phaseolus vulgaris): evidence for multiple centers of domestication. Econ Bot 40:451-468

Graham PH, Ranalli P (1997) Common bean (Phaseolus vulgaris L.). Field Crop Res 53:131-146

Guzmán-Maldonado SH, Marín-Jarillo A, Castellanos JZ, Gonzáles de Mejía E, Acosta-Gallegosc JA (1996) Relationship between physical and chemical characteristics and susceptibility to Zabrotes subfasciatus (Boh.) (Coleoptera: Bruchidae) and Acanthoscelides obtectus (Say) in common bean (Phaseolus vulgaris L.) varieties. J Stored Prod Res 32:53-58

Hancock JF (2004) Protein plants. In: Hancock JF (ed) Plant evolution and the origin of crop species, 2nd edn. CAB International, Cambridge, pp 195-208

Hartweck LM, Cardona C, Osborn C (1997) Bruchid resistance of common bean lines having an altered seed protein composition. Theor Appl Genet 95:1018-1023

Hill DS (2002) Pests: Class Insecta. In: Hill DS (ed) Pests of stored foodstuffs and their control. Kluwer Academic Publishers, Secaucus, pp 135-315

Lara FM (1991) Princípios de resistência de plantas a insetos, 2nd edn. São Paulo, Ícone, $207 \mathrm{p}$

Lioi L, Sparvoli F, Galasso I, Lanave C, Bollini R (2003) Lectin-related resistance factors against bruchids evolved through a number of duplication events. Theor Appl Genet 107:814-822

Lorini I (2002) Descrição, biologia e danos das principais pragas de grãos armazenados. In: Lorini I, Miike LH, Scussel VM (eds) Armazenagem de grãos. IBG, Campinas, pp 381-397

Mazzonetto F, Vendramim JD (2002) Aspectos biológicos de Zabrotes subfasciatus (Boh.) (Coleoptera: Bruchidae) em genótipos de feijoeiro com e sem arcelina. Neotrop Entomol 31:435-439

Minney BHP, Gatehouse AMR, Dobie P, Dendy J, Cardona C, Gatehouse JA (1990) Biochemical bases of seed resistance to Zabrotes subfasciatus (bean weevil) in Phaseolus vulgaris (common bean): a mechanism for arcelin toxicity. J Insect Physiol 36:757-767

Panda N, Khush GS (1995) Host plant resistance to insects. CAB International, Wallingford, $448 \mathrm{p}$

Pereira PAA, Yokoyama M, Quintela ED, Bliss FA (1995) Controle do caruncho Zabrotes subfasciatus (Boheman, 1833) (Coleoptera: Bruchidae) pelo uso de proteína da semente em linhagens quase isogênicas de feijoeiro. Pesq Agrop Brasileira 30:1031-1034

Rêgo AFM, Veiga AFSL, Rodrigues ZA, Oliveira ML, Reis OV (1986) Efeito da incidência de Zabrotes subfasciatus (Bohemann, 1833) (Coleoptera, Bruchidae) sobre genótipos de Phaseolus vulgaris L. An Soc Entomol Bras 15:53-69

Rossetto CJ (1966) Sugestões para armazenamento de grãos no Brasil. 0 Agronômico 18:38-51

Silva KFAS, Michereff-Filho M, Fonseca MEN, Silva-Filho JG, Texeira ACA, Moita AW, Torres JB, Fernández-Muñoz R, Boiteux LS (2014) Resistance to Bemisia tabaci biotype B of Solanum pimpinellifolium is associated with higher densities of type IV glandular trichomes and acylsugar accumulation. Entomol Exp Appl 151:218-230

Singh SP (1989) Patterns of variation in cultivated common bean (Phaseolus vulgaris, Fabaceae). Econ Bot 43:33-57

Singh SP, Gepts P, Debouck D (1991) Races of common bean (Phaseolus vulgaris, Fabaceae). Econ Bot 45:379-396

Smith CM (2005) Plant resistance to Arthropods: molecular and conventional approaches. Springer, The Netherlands, $426 \mathrm{p}$

Vendramim JD, Guzzo EC (2009) Resistência de plantas e a bioecologia e nutrição dos insetos. In: Panizzi AR, Parra JRP (eds) Bioecologia e nutrição de insetos: Base para o manejo integrado de pragas. Embrapa Informação Tecnológica, Brasília, pp 1055-1105

Vendramim JD, Guzzo EC (2012) Plant resistance and insect bioecology and nutrition. In: Panizzi AR, Parra JRP (eds) Insect bioecology and nutrition for integrated pest management. CRC Press, Boca Raton, pp 657-685 
Vilca Mallqui KS, Oliveira EE, Guedes RNC (2013) Competition between the bean weevils Acanthoscelides obtectus and Zabrotes subfasciatus in common beans. J Stored Prod Res 55:32-35

Voysest O, Valencia MC, Amezquita MC (1994) Genetic diversity among Latin American Andean and Mesoamerican common bean cultivars. Crop Sci 34:1100-1110

Wanderley VS, Oliveira JV, Andrade ML Jr (1997) Resistência de cultivares e linhagens de Phaseolus vulgaris L. a Zabrotes subfasciatus (Boh.) (Coleoptera: Bruchidae). An Soc Entomol Bras 26:315-320

Zaugg I, Magni C, Panzeri D, Daminati M, Bollini R, Benrey B, Bacher S, Sparvoli F (2013) QUES, a new Phaseolus vulgaris genotype resistant to common bean weevils, contains the Arcelin-8 allele coding for new lectin-related variants. Theor Appl Genet 126:647-661 